\title{
ANTIDUMPING BEYOND THE GATT 1994: SUPPORTING INTERNATIONAL ENACTMENT OF LEGISLATION PROVIDING SUPPLEMENTAL REMEDIES
}

\section{INTRODUCTION}

The General Agreement on Tariffs and Trade (General Agreement or GATT) ${ }^{1}$ has been characterized as a major force in the promotion of international peace and prosperity. ${ }^{2}$ The GATT accomplished global peace and prosperity by establishing a nondiscriminatory trade environment by reducing tariffs and other barriers to international trade. ${ }^{3}$ But in 1995, after seven years of negotiation, a new set of global trade rules took effect, that should make nations reconsider whether peace and prosperity are best promoted by broad-scope reductions in international trade barriers. ${ }^{4}$ These new rules are embodied in the Final Act Embodying the Results of the Uruguay Round Multilateral Trade Negotiations (Final Act). ${ }^{5}$ It is yet to be seen what the full impact will be upon the world in result of the Uruguay Round Agreements. Some studies claim economic prosperity will shower the earth while other studies claim that the industrial world will become destabilized and impoverished while the third world will be cruelly ravaged. ${ }^{\circ}$ One of the areas of the agreement that continues to divide critics is the

1. General Agreement on Tariffs and Trade, Oct. 30, 1947, 61 Stat. A-3, 55 U.N.T.S. 187 [hereinafter GATT].

2. See Roger P. Alford, Note, Why a Private Right of Action Against Dumping Would Violate GATT, 66 N.Y.U. L. REV. 696, 696 (1991).

3. See id.

4. See Joseph F. Dennin, Introduction to [Treaties Binder 1] LAW \& PRACTICE OF THE WORLD TRADE ORGanization (Joseph F. Dennin ed., 1995).

5. Apr. 15, 1994, [Treaties Binder 1] LAW \& Practice OF THE WORLD TRADE ORganization 5 (1995), 33 I.L.M. 1125 (1994) [hereinafter Final Act]. For a detailed breakdown of the components of the Final Act, see Philip Raworth, WTO: Introduction, in [Commentary Binder 1] LAW \& PRACTICE Of THE WORLD TRAdE ORGanization, at A-13 (Joseph F. Dennin ed., 1995). Of importance here, the central component of the Final Act, the Marrakesh Agreement Establishing the World Trade Organization (WTO Agreement), contains the multilateral agreements on trade in goods under Annex 1A. See id. Annex 1 A contains the GATT, which is now popularly recognized as the General Agreement on Tariffs and Trade 1994 (GATT 1994). See id. See also 19 U.S.C. \$1677(31)(1994)("The term 'GATT 1994' means the General Agreement on Tariffs and Trade annexed to the WTO Agreement.").

6. Dennin, supra note 4. Dennin notes that "few of those who debated the Final Act's implementing legislation, and fewer still of those who would be significantly affected by it, had a first-hand familiarity with the Act's thousand-plus pages of agreements, understandings, decisions and schedules." Id. This general lack of familiarity with the whole of the Final Act has bred uncertainty over what its end will hold for the nations of the world. Division among the critics is a natural result of the uncertainty. 
implementation and extent of antidumping measures in the GATT $1994 .^{7}$

\section{A. Dumping Defined}

Before discussing antidumping measures, it is necessary to understand what dumping is in the context of international trade. To begin, "[n]o serious examination has ever been undertaken to determine exactly what a proper definition of dumping should be." 8 Nevertheless, the GATT 1994 has defined dumping as introducing a product of a country "into the commerce of another country at less than its normal value. $"$ Less than normal value is defined as:

less than the comparable price, in the ordinary course of trade, for the like product when destined for consumption in the exporting country.

When there are no sales of the like product in the ordinary course of trade in the domestic market of the exporting country or when ... such sales do not permit a proper comparison, the margin of dumping shall be determined by comparison with a comparable price of the like product when exported to an appropriate third country, provided that this price is representative, or with the cost of production in the country of origin plus a reasonable amount for administrative, selling and general costs and for profits. ${ }^{10}$

In contrast, U.S. courts have used this definition for dumping: "“price discrimination between purchasers in different national markets.""11

7. See Alan M. Dunn, Antidumping, in The World Trade Organization: The Multilateral Trade FramewORK FOR THE 21 ST CENTURY AND U.S. IMPLEMENTING LEgisLAtion 239, 282 (Terence P. Stewart ed., 1996); Alford, supra note 2, at 697 . The antidumping measures are located in the Agreement on Implementation of Article VI of the General Agreement on Tariffs and Trade 1994, Apr. 15, 1994, Marrakesh Agreement Establishing the World Trade Organization [hereinafter WTO Agreement], Annex 1A, [Treaties Binder 1] LAW \& PRACTICE OF THE WORLD TRADE ORGANIZATION, at I-167 (1995), 33 I.L.M. 1144 (1994) [hereinafter Antidumping Agreement].

8. Gary N. Horlick \& Eleanor C. Shea, The World Trade Organization Antidumping Agreement, 7 INT'L Q. 685, 688 (1995). The practice of dumping has been known to exist long before World War I. See Zenith Radio Corp. v. Matsushita Elec. Indus. Co., Ltd., 402 F. Supp. 251, 259 (E.D. Penn. 1975).

9. Antidumping Agreement art. 2, para. 1.

10. Antidumping Agreement art. 2, paras. 1-2.

11. Zenith Radio Corp. v. Matsushita Elec. Indus. Co., Ltd., 723 F.2d 319, 322 (3d Cir. 1983), rev'd in part, 475 U.S. 574 (1986); Zenith Radio Corp. v. Matsushita Elec. Indus. Co., Ltd., 494 F. Supp. 1190, 1194 (E.D. Penn. 1980), rev'd in part, 723 F.2d 319 (3d Cir. 1983), 
Several types of dumping-sporadic, continuous, and predatory-have been recognized. ${ }^{12}$ Sporadic dumping is the "occasional sale of overstock" in the international marketplace at greatly reduced prices. ${ }^{13}$ There may be a particular urgency to sell overstock of perishable goods quickly for example. ${ }^{14}$ The foreign manufacturer's intention is to relieve itself of excess inventory while keeping the price of its products stable in its home market. ${ }^{15}$

Continuous dumping seeks to achieve economies of scale. ${ }^{16}$ Manufacturing a larger volume of goods is generally more efficient because the marginal cost of producing each unit is reduced, thereby reducing total costs for the manufacturer. ${ }^{17}$ Not only are the manufacturer's fixed costs (or overhead) spread over the greater number of units produced, its variable costs (or unit cost) are reduced as the manufacturer becomes more efficient at producing each extra unit. ${ }^{18}$ This is known as the experience curve. ${ }^{19}$ "Provided a product's average price exceeds its average cost of production, the producer is assured a sustained profit from overall sales."20 But it is important to note that continuous dumping manufacturers have a long term perspective on profits. Often the manufacturer will not significantly benefit from increased production via the experience curve in the short term, and so,

rev'd in part, 475 U.S. 574 (1986); Zenith Radio, 402 F. Supp. at 259 (quoting J. VINER, DUMPING: A Problem IN INTERNATIONAL TRADE 4 (1923)). Under 19 U.S.C. $\$ 1677(34)$ (1994), "the sale or likely sale of goods at less than fair value" is dumping.

12. See Alford, supra note 2, at 703 . A last, unusual type of dumping is claimed to exist- social dumping. Social dumping is caused when a manufacturer sells its product at a lower price than comparable products in a foreign market as a result of lower labor or environmental standards in its home market. See GABRIELLE MARCEAU, ANTI-DUMPING AND ANTI-TRUST ISSUES IN FREE-TRADE AREAS 50 (1994). For environmentalists, social dumping also extends to products that are sold at a lower price than comparable products in a foreign market as a result of savings gained from manufacturing a less environmentally-friendly product. See id. at 50 n. 185 .

13. Alford, supra note 2, at 703. See also Bart S. Fisher, The Antidumping Law of the United States: A Legal and Economic Analysis, 5 LAW \& POL'Y INT'L BUS. 85, 88 (1973).

14. See Jewel Foliage Co. v. Uniflora Overseas Fla., Inc., 497 F. Supp. 51 3, 518 (M.D. Fla. 1980).

15. See Alford, supra note 2, at 703-04.

16. See Fisher, supra note 13, at 89; Alford, supra note 2, at 703.

17. See Fisher, supra note 13, at 89; Alford, supra note 2, at 703. See also Stephen F. Moller, Comment, Free Trade Realism in the International Market: Towards a Sensible, Privately-Enforced Antidumping Statute, 33 SANTA CLARA L. REV. 931 , 939 (1993).

18. See generally Alford, supra note 2, at 703-04; Moller, supra note 17, at 938-40.

19. See Moller, supra note 17, at 940. Moller also states in his hypothetical: "The doubling of production and sales of a product reduces the total cost of taking the product to the market place by twenty to thirty percent." Id.

20. Alford, supra note 2, at 704. See also Fisher, supra note 13 , at 89 . Thus, even if the manufacturer fails to sell its entire inventory, continuous dumping may be profitable. However, there will be an optimal amount of production for the manufacturer that will maximize total profits. This optimal point will depend on the conditions of supply and demand in the market for the manufacturer's product. 
operate at a loss. The manufacturer is gambling that the short term losses will be outweighed by the long term profits as the experience curve cost reductions accelerate.

Predatory dumping is hostile in nature because it is used to forestall the development of or eliminate competition through aggressive price cutting. ${ }^{21}$ The manufacturer's intent is to gain market share or a monopoly. ${ }^{22}$ Once the producer meets its aim by crushing the competition, it raises the prices on its goods to recover its losses from the price cutting. ${ }^{23}$

What all three types of dumping have in common is that all promote market inefficiency. ${ }^{24}$ Producers that resort to dumping are engaging in unfair price competition. ${ }^{25}$ By reducing prices below cost of production and a reasonable profit (an inefficient act), producers seek to drive out the competition, gain market share, and ultimately reap monopoly profits. ${ }^{26}$ This is most obvious with predatory dumping. In the case of continuous dumping, a manufacturer is assured that its long term profits outweigh its short term losses through a monopoly in its market at the end of the short term. Even sporadic dumping is inefficient since "its purpose is to minimize losses that are then passed on to competitors."27 Efficient producers are able to absorb their own losses and continue to compete without resorting to dumping schemes in an efficient market. ${ }^{28}$

\section{B. The Current State of Antidumping Measures}

The United States government and the European Community Commission see themselves as "users of antidumping laws, rather than as exporting countries." 29 Since the United States and the European Community are the world's largest exporters, this stance may seem rather unusual. ${ }^{30}$ In some respects, this stance reflects trade politics where such countries with large internal markets are able to advocate protectionism over access to international markets for their exports. ${ }^{31}$ But it is undeniable that such countries are also seen as attractive markets to the would be dumper since

21. See John J. Barcelo III, Antidumping Laws as Barriers to Trade-TheUnited States and the International Antidumping Code, 57 CORNELL L. REV. 491, 499 (1972); Alford, supra note 2 , at 704 .

22. See Barcelo, supra note 21, at 499; Alford, supra note 2, at 704.

23. See Barcelo, supra note 21, at 500; Alford, supra note 2, at 704.

24. See Alford, supra note 2, at 704.

25. See id.; Moller, supra note 17, at 967.

26. See Alford, supra note 2, at 704-05; Moller, supra note 17, at 967.

27. Moller, supra note 17 , at 967.

28. See id.; Alford, supra note 2 , at 704.

29. Horlick \& Shea, supra note 8, at 692.

30. See id.

31. See id. 
their consumers have the wealth to buy many products beyond their basic needs.

In response to dumping concerns, the General Agreement's remedy to injurious dumping is the use of antidumping duties. ${ }^{32}$ However, U.S. producers claim that the GATT 1994 does not go far enough to protect them from dumping. ${ }^{33}$ In particular, the GATT 1994 does not allow the injured producers to collect damages from the dumper. ${ }^{34}$ Thus, if the imposition of an antidumping duty is slow to occur, the dumper may gain a significant market share advantage against its competitors. ${ }^{35}$ Furthermore, since retroactive duties are limited, ${ }^{36}$ dumping becomes a "risk[-]free, no-lose proposition." ${ }^{37}$

Despite the lack of a private remedy for injured producers in the GATT 1994, currently the United States allows a private right of action against dumpers through the 1916 Antidumping Act $\left(1916\right.$ Act). ${ }^{38}$ The 1916 Act provides criminal penalties and allows civil damages to be collected from dumpers. ${ }^{39}$ But for the fact that this obscure law was never abrogated when the United States implemented the GATT 1994, the 1916 Act stands in clear contradiction to the express remedies provided in the General Agreement. ${ }^{40}$ Such nontariff barriers by the United States are said to deteriorate the GATT $1994 .{ }^{41}$

Many critics have claimed that the 1916 Act is ineffective against dumping. ${ }^{42}$ In fact, only three years after its enactment, the U.S. Tariff Commission agreed that the Act was ineffective. ${ }^{43}$ However, within roughly the past thirty years, the 1916 Act has gained in popularity as both a weapon to halt and a salve to heal injurious dumping. ${ }^{44}$ Currently there is a complaint

32. See Philip Raworth, Agreement on Implementation of Article VI of the General Agreement on Tariffs and Trade 1994 ("Anti-Dumping Code"), in [Commentary Binder 1] LAW \& PRACTICE OF ThE WORLD TRADE ORGanization B-35, B-40 (Joseph F. Dennin ed., 1995); Alford, supra note 2, at 726.

33. See Moller, supra note 17, at 950-51; Alford, supra note 2, at 697-98.

34. See Raworth, supra note 32, at B-40; Alford, supra note 2, at 698; Moller, supra note 17 , at $950-51$.

35. See Moller, supra note 17, at 951.

36. See Raworth, supra note 32, at B-40; Alford, supra note 2, at 698.

37. Alford, supra note 2, at 698.

38. 15 U.S.C. $\$ 72(1994)$.

39. See id.

40. See John Zarocostas, E.U. Seeks to Stop Obscure U.S. Law, 20 NAT'L L.J. A12 (1998).

41. See Marie Louise Hurabiell, Comment, Protectionism Versus Free Trade: Implementing the GATT Antidumping Agreement in the United States, $16 \mathrm{U}$. PA. J. INT'L. BUS. L. 567,577 (1995).

42. See id. at 575; Alford, supra note 2, at 712; Moller, supra note 17, at 950.

43. See Moller, supra note 17 , at 952.

44. See Geneva Steel Co. v. Ranger Steel Supply Corp., 980 F. Supp. 1209, 1214 (D. Utah 1997). 
filed by the European Union with the World Trade Organization demanding that the law be repealed for being in violation of the GATT $1994 .{ }^{45}$ Although a case has never been successful on the merits under the $1916 \mathrm{Act},{ }^{46}$ the mere threat of litigation may have a positive effect on the discouragement of dumping. On the other hand, the European Union claims that the 1916 Act only disrupts trade. ${ }^{47}$

Either way, the decision reached by the World Trade Organization has special significance because the panel decision will be binding (unless there is a consensus to reject the decision) as a result of the Uruguay Round Agreements. ${ }^{48}$ Thus, it is important to recognize the goals of the 1916 Act and the Act's usefulness as a tool to achieve both the goals of the Act and of the GATT 1994. Nations should have the flexibility under the GATT 1994 to pass legislation entitling their citizens to supplementary remedies, particularly to a private antidumping remedy, to resolve shortcomings of the GATT 1994 remedies, benefit domestic economies, and ultimately strengthen national security.

Before proceeding, it is useful to understand the history of the 1916 Act. This history from the Act's inception is detailed in Part II. Afterward, details of the GATT 1994 and the remedies provided therein will be discussed, and a comparison of the GATT 1994 remedies with those of the 1916 Act will be made in Part III. Before concluding, the advantages of supplementary remedies to the GATT 1994 will be presented in Part IV.

\section{HISTORY OF THE 1916 ANTIDUMPING ACT}

The first antidumping law in the United States was the 1916 Antidumping Act. ${ }^{49}$ The 1916 Act is still unique because it is the only U.S. law against dumping that is not administratively enforced. ${ }^{50}$ The purpose behind the Act is to "protect domestic industries from dumping by their

45. See Zarocostas, supra note 40 , at A12. The European Union decided to file the complaint after informal talks with the United States failed to persuade the United States to repeal the law. See Richard Lawrence, E.U. Fights 1916 U.S. Law in Steel Anti-Dumping Case, J. OF COM., Oct. 23, 1997, at 2A, available in LEXIS, News Library, Joc File.

46. See Moller, supra note 17, at 941 . See also Geneva Steel, 980 F. Supp. at 1214. But there is one instance in which a plaintiff prevailed in an unpublished default judgment. See Consolidated Int'l Automotive, Inc. v. Chen, 51 F.3d 279, 1995 WL 139347 (9th Cir. 1995).

47. See Zarocostas, supra note 40 , at A12.

48. See Dennin, supra note 4. It is also important to recognize how many countries will be impacted by any decision made. In 1947, the GATT had only 23 participating countries. See Hurabiell, supra note 41 , at 569 n.12. In contrast, 124 countries participated in the Uruguay Round. See id.

49. See Moller, supra note 17 , at 941.

50. See id. at 939. 
foreign competitors." ${ }^{\text {"1 }}$ The text of the Act makes this purpose quite apparent:

It shall be unlawful for any person importing or assisting in importing any articles from any foreign country into the United States, commonly and systematically to import, sell or cause to be imported or sold such articles within the United States at a price substantially less than the actual market value or wholesale price of such articles, at the time of exportation to the United States, in the principal markets of the country of their production, or of other foreign countries to which they are commonly exported after adding to such market value or wholesale price, freight, duty, and other charges and expenses necessarily incident to the importation and sale thereof in the United States: Provided, That such act or acts be done with intent of destroying or injuring an industry in the United States, or of preventing the establishment of an industry in the United States, or of restraining or monopolizing any part of trade and commerce in such articles in the United States. ${ }^{52}$

The main interest that the 1916 Act seeks to protect is that of domestic manufacturers. ${ }^{53}$ But courts have also recognized that the Act protects U.S. importers as well. ${ }^{54}$

\section{A. Legislative History}

This move to protect domestic industry stemmed from Congressional concerns about the aftermath of World War I. ${ }^{\text {ss }}$ During World War I, American enterprise was doing especially well. ${ }^{56}$ This success was due to a

51. Western Concrete Structures Co., Inc. v. Mitsui \& Co. (U.S.A.), Inc., 760 F.2d 1013, 1019 (9th Cir. 1985). See also Moller, supra note 17, at 944.

52. 15 U.S.C. $\$ 72$ (1994) (emphasis added).

53. See Schwimmer v. Sony Corp. of Am., 471 F. Supp. 793, 797 (E.D.N.Y. 1979).

54. See Western Concrete, 760 F.2d at 1019; Isra Fruit Ltd. v. Agrexco Agric. Export Co. Ltd., 631 F. Supp. 984, 989 (S.D.N.Y. 1986); Jewel Foliage Co. v. Uniflora Overseas Fla., Inc., 497 F. Supp. 513, 516 (M.D. Fla. 1980). In Isra Fruit, the court held that allowing only manufacturers to "vindicate their losses," and not importers, "does not fairly perceive the consequences of the illegal activity. The harm to the markets of the United States being the same, the importer should not be denied the right to avail itself of the [1916] Act's protections." 631 F. Supp. at 989.

55. See Zenith Radio Corp. v. Matsushita Elec. Indus. Co., Ltd., 494 F. Supp. 1 190, 1219 (E.D. Penn. 1980), rev'd in part, 723 F.2d 319 (3d Cir. 1983), rev'd in part, 475 U.S. 574 (1986); Geneva Steel Co. v. Ranger Steel Supply Corp., 980 F. Supp. 1209, 1212 (D. Utah 1997).

56. See Zenith Radio, 494 F. Supp. at 1219; Geneva Steel, 980 F. Supp. at 1212. 
lack of European competition because European resources were turned toward national defense. ${ }^{57}$ Importation of competing European goods was "impossible," and "American goods which had previously been made only under the shelter of high duties were exported heavily to markets abroad." But there was a fear that U.S. fortune would fade when the war ended. ${ }^{59}$ It was believed that European manufacturers, which had been actively engaged in supporting the war effort, would aggressively try to recover the market share they had lost in the United States. ${ }^{60}$ Next, there was a "rise of antiGerman sentiment" and a "widespread popular conviction that German enterprises were particularly vicious perpetrators of predatory dumping" during this period..$^{61}$ This in part caused pressure to increase tariffs in the United States. ${ }^{62}$ Additionally, the Republican Party strongly supported protective tariffs during this period. ${ }^{63}$ Republicans felt that tariffs offered the best defense against foreign competition which would allow America to diversify its industries, develop its resources, and preserve national employment for its workers. ${ }^{64}$

There was also a strong political atmosphere in the United States that was opposed to the creation of cartels and monopolies. ${ }^{65}$ After all, just two years prior to the Act's passage (1914), the Sixty-Third Congress passed such legislation as the Clayton Antitrust Act, $^{66}$ which prohibited price discrimination. ${ }^{67}$ Price discrimination was seen as "an important contributor

57. See Geneva Steel, 980 F. Supp. at 1212.

58. Zenith Radio, 494 F. Supp. at 1219.

59. See id.; Geneva Steel, 980 F. Supp. at 1212.

60. See Zenith Radio, 494 F. Supp. at 1219, 1222; Geneva Steel, 980 F. Supp. at 1212.

61. J. Michael Finger, The Origins and Evolutions of Antidumping Regulation, in ANTIDUMPING: How IT WORKS AND WHO GETS HURT 13, 18 (J. Michael Finger \& Nellie T. Artis eds., 1993).

62. See id.

63. See Zenith Radio, 494 F. Supp. at 1218-19.

64. See id. In 1912, the Republican Party Platform stated:

We re[-]affirm our belief in a protective tariff. The Republican tariff policy has been of the greatest benefit to the country, developing our resources, diversifying our industries, and protecting our workmen against competition with cheaper labor abroad, thus establishing for our wage-earners the American standard of living. The protective tariff is so woven into the fabric of our industrial and agricultural life that to substitute for it a tariff for revenue only would destroy many industries and throw millions of our people out of employment.

Id. (quoting from NATIONAL. PARTY PLATFORMS, 1840-1956, at 168-69 (K. Parker \& D. Johnson eds., 1956)).

65. See Moller, supra note 17, at 944. "The Democratic Congresses, consonant with Party tradition in the era [the early twentieth century], were vigorously opposed to anticompetitive and monopolistic practices." Zenith Radio, 494 F. Supp. at 1217.

66. 15 U.S.C. $\$ 12$ et seq. (1994). See in particular 15 U.S.C. $\$ 13$.

67. See Zenith Radio, 494 F. Supp. at 1217 (outlining the history of U.S. antitrust law). 
to the growth of monopoly." ${ }^{68}$ In fact, the 1916 Act is "functionally similar" to the Clayton Antitrust Act in terms of its prohibition on price discrimination, but it applies the prohibition to international commerce. ${ }^{69}$

Unlike the Republicans, the Democratic Party favored lower tariffs. ${ }^{70}$ The Democrats believed that lower tariffs would create competition against domestic cartels by allowing foreign manufacturers increased access to the U.S. marketplace. ${ }^{71}$ However, the Democrats were also wary of the possibility of the use of unfair trade practices such as dumping by European manufacturers. ${ }^{72}$ Thus, in order to protect newly created and expanding industries in the United States, and yet stay true to its opposition to protective tariffs, the 1916 Act was recommended by President Woodrow Wilson's administration. ${ }^{73}$

The result was that the Antidumping Act was signed into law on September $8,1916 .^{74}$ The Act was contained in section 801 of the Revenue Act of $1916 .{ }^{75}$ During its passage, there was "very little debate on the antidumping clause" in Congress. ${ }^{76}$ But it was clear that Congress was afraid of unfair European competition and that, through the 1916 Act, Congress intended to place foreign producers on the same footing as domestic producers

68. Id.

69. Id. at 1213.

70. Helmac Products Corp. v. Roth (Plastics) Corp., 814 F. Supp. 560, 566 (E.D. Mich. 1992). Note that the Democratic Party had a majority in both houses of Congress throughout this period, 1913-1917. See Zenith Radio, 494 F. Supp. at 1217.

71. See Moller, supra note 17, at 944 . The Democratic Party Platform of 1912 stated:

We declare it to be a fundamental principle of the Democratic [P]arty that the Federal government, under the Constitution, has no right or power to impose or collect tariff duties, except for the purpose of revenue, and we demand that the collection of such taxes shall be limited to the necessities of government honestly and economically administered. The high Republican tariff is the principal cause of the unequal distribution of wealth; it is a system of taxation which makes the rich richer and the poor poorer; under its operations the American farmer and laboring man are the chief sufferers; it raises the cost of the necessaries of life to them, but does not protect their product or wages. ... We favor the immediate downward revision of the existing high and in many cases prohibitive tariff duties, insisting that material reductions be speedily made upon the necessaries of life. Articles entering into competition with trust-controlled products and articles of American manufacture which are sold abroad more cheaply than at home should be put upon the free list.... We appeal to the American people to support us in our demand for a tariff for revenue only.

Zenith Radio, 494 F. Supp. at $1217-18$ (alteration in original) (quoting from NATIONAL PARTY PLATFORMS, 1840-1956, at 168-69 (K. Parker \& D. Johnson eds., 1956)).

72. See Helmac Products, 814 F. Supp. at 566; Moller, supra note 17, at 944.

73. See Helmac Products, 814 F. Supp. at 566; Zenith Radio, 494 F. Supp. at 1220.

74. See Zenith Radio, 494 F. Supp. at 1217.

75. See id. at 1220.

76. Id. at 1221 . 
that were constrained by federal antitrust law. ${ }^{77}$

After enactment, it was not until 1935 that a judicial opinion was published citing the 1916 Act. $^{78}$ Until 1980, there had never been a case decided on its merits under the Act. ${ }^{79}$

\section{B. A Protectionist Versus an Antitrust Statute}

The slow development of the case law along with the lack of Congressional debate has left some fundamental questions about the 1916 Act unanswered. One such issue is whether the Act is essentially a protectionist statute or an antitrust statute. Logically, the 1916 Act has both an antitrust element and a protectionist element.

In Geneva Steel Co. v. Ranger Steel Supply Corp. ${ }^{80}$ the issue was raised whether the plaintiff needed to allege an antitrust injury or predatory pricing in order to state a claim under the 1916 Act. In resolving the issue, the court held that the Act's plain meaning applied. ${ }^{81}$ The court found that the plaintiff only needed to allege that the defendant lowered prices with the intent to destroy, injure, or prevent the establishment of an industry of the United States to state a claim. ${ }^{82}$ Therefore, since the Act was "designed to protect United States industry," the 1916 Act was not simply an antitrust statute, and hence, antitrust injury or predatory price discrimination was not essential in making a claim. ${ }^{83}$

However, in contrast, the court in Zenith Radio Corp. v. Matsushita Electric Industrial Co., Ltd. ${ }^{84}$ came to the opposite conclusion. Based on the similarities between the text of the 1916 Act and the text of the Clayton Antitrust Act of 1914 and other antitrust laws in terms of standing, damage provisions, penalties, and language, the court held that the 1916 Act was an antitrust, not a protectionist, statute. ${ }^{85}$ Similarly, in Helmac Products Corp. $v$. Roth Corp. ${ }^{86}$ the court held that a period of four years was appropriate for the statute of limitations under the 1916 Act after examining its legislative

77. See id. at 1221-23.

78. See Zenith Radio Corp. v. Matsushita Elec. Indus. Co., Ltd., 402 F. Supp. 251, 254 (E.D. Penn. 1975). The first reported opinion was H. Wagner \& Adler Co. v. Mali, 74 F.2d 666 (2d Cir. 1935).

79. See Moller, supra note 17 , at 941 .

80. 980 F. Supp. 1209 (D. Utah 1997).

81. See id. at 1215.

82. See id. To view the relevant language of the 1916 Act, see supra emphasized text accompanying note 52 .

83. Geneva Steel, 980 F. Supp. at 1215. Accord Wheeling-Pittsburgh Steel Corp. v. Mitsui \& Co., 35 F. Supp. 2d 597, 604 (S.D. Ohio 1999).

84. 494 F. Supp. 1190 (E.D. Penn. 1980), rev'd in part, 723 F.2d 319 (3d Cir. 1983), rev'd in part, 475 U.S. 574 (1986).

85. See id. at 1214-15.

86. 814 F. Supp. 560 (E.D. Mich. 1992). 
history because the Act was analogous to the antitrust statutes, such as the Clayton Antitrust Act. ${ }^{87}$ But the court also said that the 1916 Act need not be "interpreted consistently with the antitrust statutes in all situations."

Although opinions are divided in the courts and among the commentators, ${ }^{89}$ the narrow antitrust view overlooks the protection given especially to U.S. industry in the plain meaning of the Act. The antitrust view has been dominant in the past, but the broader interpretation that recognizes a protectionist bent in the Act is gaining hold. Given the strength of the argument that recognizes both the antitrust and protectionist attributes, the trend can be expected to continue.

\section{Application Difficulties of the Act}

Perhaps the greatest criticism that can be leveled against the 1916 Act is that it has been ineffective in deterring dumping." For example, "there have been four attempts to enforce the criminal provisions of the Act, but none was [sic] successful." numerous, have also had little success. ${ }^{92}$

There are two reasons for the 1916 Act's ineffectiveness: difficulties in obtaining evidence and difficulties in proving the required intent. ${ }^{93}$ Because the 1916 Act is both a civil and a criminal statute, the Fifth Amendment will prevent discovery of evidence that may tend to incriminate the defendant if the defendant is an individual. ${ }^{94}$ Proving intent is also burdensome because specific predatory intent is required under the 1916 Act. ${ }^{95}$ However, the predatory intent requirement may be established by inference, even if the defendant has only a "small market share" that makes successful injury of

87. See id. at 566-67.

88. Id. at 567.

89. For example, see Moller, supra note 17, at $942-45$, for the antitrust view of the 1916 Act, and see Note, Rethinking the 1916 Antidumping Act, 110 HARV. L. REV. 1555 (1997), for the protectionist viewpoint.

90. See Moller, supra note 17, at 950-51; Alford, supra note 2, at 713. 1997).

91. Geneva Steel Co. v. Ranger Steel Supply Corp., 980 F. Supp. 1209, 1214 (D. Utah

92. See id.; Moller, supra note 17, at 951 . "However, a filing [under the 1916 Act] is not categorically frivolous merely because of the probable difficulties a plaintiff faces bringing a claim." Consolidated Int'I Automotive, Inc. v. Chen, 51 F.3d 279, 1995 WL 139347, at *2 (9th Cir. 1995).

93. See Moller, supra note 17 , at 952.

94. See id.; H. Wagner \& Adler Co. v. Mali, 74 F.2d 666, 669-70 (2d Cir. 1935).

95. See Zenith Radio Corp. v. Matsushita Elec. Indus. Co., Ltd., 402 F. Supp. 251,259

(E.D. Penn. 1975); Alford, supra note 2, at 712. 
American industry unlikely. ${ }^{96}$ Thus, given the broad net that is cast, it is sensible to require some amount of difficulty in proving liability under the 1916 Act so that the innocent are not ensnared.

\section{Remedies Provided}

As previously mentioned, the 1916 Act provides both criminal and civil penalties. ${ }^{97}$ Although this has been claimed to be a handicap, ${ }^{98}$ it is not uncommon to provide both types of penalties in a statute, ${ }^{99}$ such as with the federal RICO statute. ${ }^{100}$ The full text of the penalties under the 1916 Act follow:

Any person who violates or combines or conspires with any other person to violate this section is guilty of a misdemeanor, and, on conviction thereof, shall be punished by a fine not exceeding $\$ 5,000$, or imprisonment not exceeding one year, or both, in the discretion of the court.

Any person injured in his business or property by reason of any violation of, or combination or conspiracy to violate, this section, may sue therefor in the district court of the United States for the district in which the defendant resides or is found or has an agent, without respect to the amount in controversy, and shall recover threefold the damages sustained, and the cost of the suit, including a reasonable attorney's fee. ${ }^{101}$

With the difficulties in obtaining evidence and proving the Act's required intent, the criminal penalties are comparatively light. However, the treble damages available in a successful civil suit are attractive in spite of these difficulties. The potential severity of the damages may even encourage defendants to settle before the case comes to trial.

96. Zenith Radio Corp. v. Matsushita Elec. Indus. Co., Ltd., 494 F. Supp. 1190, 1201 n. 12 (E.D. Penn. 1980), rev'd in part, 723 F.2d 319 (3d Cir. 1983), rev'd in part, 475 U.S. 574 (1986). For a discussion of the predatory intent required in domestic antitrust statutes as compared to the 1916 Act, see generally Wheeling-Pittsburgh Steel Corp. v. Mitsui \& Co., 35 F. Supp. 2d 597 (S.D. Ohio 1999).

97. See supra text accompanying note 39.

98. See Moller, supra note 17, at 952.

99. See Geneva Steel Co. v. Ranger Steel Supply Corp., 980 F. Supp. 1209, 1216 (D. Utah 1997).

100. See Racketeer Influenced and Corrupt Organizations Act, 18 U.S.C. $\S \S 1961-68$ (1994).

101. 15 U.S.C. $\$ 72$ (1994) (emphasis added). 


\section{A COMPARISON OF ANTIDUMPING UNDER THE GATT 1994 AND THE 1916 ACT}

\section{A. The Principles of the GATT 1994 and Antidumping}

The General Agreement is based on three central principles: trade liberalization, nondiscriminatory trade, and multilateral negotiations on trade. $^{102}$ The first principle, trade liberalization, essentially means the reduction of tariff and nontariff barriers to trade. ${ }^{103}$ The second principle, nondiscrimination, requires that all World Trade Organization members are to give equal treatment to other members. Furthermore, products of foreign origin are to receive "no less favorable treatment than products of domestic origin." 104 The third and last principle, multilateral negotiations, means that trade conditions are to be discussed such that the terms of the agreement are "'reciprocal and mutually advantageous' to all" members. ${ }^{105}$

It is important to note that dumping does not violate any of the underlying principles of the GATT $1994 .{ }^{106}$ In fact, many critics note that the antidumping remedies provided in Article VI are an anomaly in the general framework of the GATT 1994. ${ }^{107}$ Article VI is seen as a compromise rather than an achievement of the negotiations since it gives countries "permission to impose import restrictions." 108 This is clearly in opposition to the General Agreement's goal of reducing barriers to international trade.

However, the antidumping provisions of the General Agreement have gained more acceptance. First, as a result of the Uruguay Round, all signatories of the Final Act must adhere to the Antidumping Agreement in order to obtain membership in the World Trade Organization. ${ }^{109}$ Second, trade liberalization, which has substantially reduced tariffs, has brought increased exposure to foreign competition for domestic producers. ${ }^{110}$ This has changed the policies of many countries. In the 1970's, "only four nations were active users of antidumping laws-Australia, New Zealand, the European

102. See Alford, supra note 2, at 701-02.

103. See id. at 701; WTO Agreement preamble, para. 4.

104. Alford, supra note 2, at 702; WTO Agreement preamble, para. 4 (The WTO Agreement calls for "the elimination of discriminatory treatment in international trade relations.").

105. Alford, supra note 2, at 702; WTO Agreement preamble, para. 4.

106. See Hurabiell, supra note 41 , at 572 .

107. See id. at 572-73; Alford, supra note 2, at 707. See also J. Michael Finger, Reform, in ANTIDUMPING: HOW IT WORKS AND WHO GETS HURT 57, 63 (J. Michael Finger \& Nellie T. Artis eds., 1993).

108. Finger, supra note 107 , at 63.

109. See Dunn, supra note 7, at 282; Philip A. Akakwam, The Standard of Review in the 1994 Antidumping Code: Circumscribing the Role of GATT Panels in Reviewing National Antidumping Determinations, 5 MINN. J. GLOBAL TrADE 277, $310 \mathrm{n} .161$ (1996).

110. See Dunn, supra note 7, at 282. 
Community," and the United States. ${ }^{\prime \prime \prime}$ Now such nations as Japan and Singapore, whose governments have been strongly against the use of antidumping measures, "have begun to apply antidumping duties in some instances." 112 Even "developing countries ... . have begun applying antidumping duties to imports with increasing frequency." 13 Thus, the trend is moving counter to the original principles of the General Agreement.

\section{B. The Conflicts Between the GATT 1994 and the 1916 Act}

Although there is increased use of antidumping measures in the GATT 1994 , it is not clear that supplemental measures such as the 1916 Act are in agreement with the GATT 1994. There are three major conflicts between the GATT 1994 and the 1916 Act that have been raised: material injury, investigation, and available remedies. ${ }^{114}$

Under the GATT 1994, antidumping measures may only be undertaken upon a showing of a "material injury to a domestic industry, threat of material injury to a domestic industry or material retardation of the establishment of such an industry." 115 What makes an injury "material" is still problematic because it is left up to national interpretation." "Material retardation" has also been left unexplained. ${ }^{117}$ The United States has defined material injury as "harm which is not inconsequential, immaterial, or unimportant." 118 Unlike the GATT 1994, material injury need not be shown under the 1916 Act. All that is required is proof that a foreign producer lowered its prices with the intent to injure, destroy, or prevent the establishment of United States industry or to restrain or monopolize trade and commerce in the subject market. ${ }^{119}$ Thus, the 1916 Act is in conflict with the GATT 1994 as to the

111. Id.

112. Id. Antidumping measures have seen increased use in the past decade. See Akakwam, supra note 109 , at 277.

113. Dunn, supra note 7, at 283.

114. Each of these conflicts has been raised as part of the European Union's complaint to the World Trade Organization over the 1916 Act.

115. Antidumping Agreement art. 3 n.9.

116. See RaINer M. Bierwagen, GaTt article VI and the Protectionist Bias IN ANTI-DUMPING LAWS 90 (1990). "The actual practice [of determining material injury] has neither the objective to relieve customs authorities of the necessity of examining every importation for possible dumping nor does it ... screen out all small cases on an equal basis, nor ensure that 'domestic industry' or welfare is harmed by reason of dumped imports." Id. at 90-91.

117. See Raworth, supra note 32, at B-39.

118. 19 U.S.C. $\$ 1677(7)(A)$ (1994). For a further examination of material injury, see BIERWAGEN, supra note 116, at 90-93.

119. See 15 U.S.C. $\$ 72(1994)$. The relevant part of the section is reproduced at supra text accompanying note 52. See also Western Concrete Structures Co., Inc. v. Mitsui \& Co. (U.S.A.), Inc., 760 F.2d 1013, 1019 (9th Cir. 1985); Geneva Steel Co. v. Ranger Steel Supply Corp., 980 F. Supp. 1209, 1215 (D. Utah 1997); Helmac Products Corp. v. Roth (Plastics) 
need to show material injury, threat, or retardation.

The GATT 1994 also requires that an investigation be held to determine imposition of antidumping measures. ${ }^{120}$ The investigation is initiated by a private application or unilaterally by government authorities. ${ }^{121}$ A private application "must be supported by domestic producers whose collective output constitutes more than [fifty percent] of the total production of those domestic producers who have expressed an opinion on the application."122 Additionally, a minimum of twenty-five percent of the total domestic production of the like product is needed by domestic producers expressly supporting the private application to initiate an investigation. ${ }^{123}$ In any case, evidence must be sufficient to show "dumping, injury, and a causal link between the two" to trigger an investigation. ${ }^{24}$ Once an investigation is initiated, a private party may appear at hearings and submit briefs, but otherwise has "little power" to affect the outcome. ${ }^{125}$ But under the 1916 Act, a private party may avoid government investigation altogether and file suit directly in a federal district court. ${ }^{126}$ Such action is in conflict with the requirement of investigation before any dumping remedy may be had under the GATT 1994.

Last, the General Agreement has three available remedies: "provisional measures, undertakings and definitive antidumping duties." 27 Provisional measures include duties, cash deposits, or bonds imposed as a result of a "preliminary affirmative determination of dumping causing injury." 128 An exporter may also give a "voluntary undertaking to revise prices or to cease dumping" after a preliminary affirmative determination. ${ }^{129}$ Last, definitive antidumping duties are available upon a final determination of material injury, threat of material injury, or material retardation. ${ }^{130}$ In any case, the duties

Corp., 814 F. Supp. 560, 574 (E.D. Mich. 1992).

120. See generally Antidumping Agreement art. 5 . The new provisions in the Antidumping Agreement regarding initiation of investigations are "intended to make the process more transparent and fair and to protect against frivolous claims." Horlick \& Shea, supra note 8 , at 703.

121. See Raworth, supra note 32, at B-39.

122. Id.

123. See id.

124. Id. See also Horlick \& Shea, supra note 8, at 703.

125. See Alford, supra note 2, at 710.

126. See 15 U.S.C. $\$ 72$, para. 3 (1994).

127. Raworth, supra note 32, at B-40. See generally Antidumping Agreement arts. 7-9.

128. Raworth, supra note 32 , at B-40. The provisional measures must also be deemed necessary to prevent continued injury to the domestic industry during the investigation. See id.

129. Id.

130. See id. 
"may not exceed the margin of dumping." criminal and civil remedies are unlike the remedies provided in the GATT 1994. ${ }^{132}$ These remedies are also not in accord with the GATT 1994 principles of trade liberalization (the 1916 Act is a nontariff barrier) and nondiscriminatory trade (dumping nations are treated less favorably than nondumping nations under the 1916 Act). ${ }^{133}$ Thus, the 1916 Act again conflicts with the GATT 1994.

\section{The 1916 Act, the GATT 1994, and Lacunae}

Given the conflicts between the 1916 Act and the GATT 1994 (material injury, investigation, and available remedies), it would appear that the 1916 Act violates the GATT 1994. But this is not necessarily the case. Although the Antidumping Agreement is exhaustive in that World Trade Organization members are not allowed to take independent antidumping measures, it is unclear whether the Antidumping Agreement is "'self-contained,' [i.e.] whether lacunae ${ }^{134}$ may only be filled by the GATT, now by the WTO [World Trade Organization], and possibly through dispute settlement procedures." 135

131. Id. The margin of dumping is the difference between the normal value of the dumped goods and their export price. Id. at B-37. For a detailed explanation over how normal value is determined, see $i d$. at B-37 to B-38. See supra note 10 and accompanying text, for the general guidelines for determining normal value in the Antidumping Agreement. When domestic sales in the exporting country are too few to make the normal value determination by comparable price, the United States prefers to use third country prices to assess the normal value. See Raworth, supra note 32, at B-37. By comparison, the European Union finds third country prices unreliable, and prefers to use the alternative method, which is the exporter's cost of production plus other reasonable costs and a reasonable profit. See id. at B-37 to B-38. Export price is typically determined by the transaction price listed in the commercial invoice. See id. at B-38. See id., for more information on export price determination. Upon determination of normal value and export price, to calculate the margin of dumping, the comparison made between them must be "at the same level of trade (normally ex factory) and[,] in respect of sales made[,] at nearly as possible the same time." Id. Typically, either a comparison of weighted-average prices or individual transaction prices is made. See id.; Horlick \& Shea, supra note 8, at 705. For more details on this comparison, see Raworth, supra note 32, at B-38. If the resulting margin of dumping is "less than $2 \%$ of the export price, it is considered de minimis." $/ d$. When the margin of dumping is de minimis, "[t]here shall be immediate termination" of the investigation and no antidumping duties shall be imposed. Antidumping Agreement art. 5, para. 8. See Raworth, supra note 32, at B-38; Horlick \& Shea, supra note 8, at 708.

132. See Alford, supra note 2 , at 726 .

133. See id.

134. Lacunae is a term which means missing parts, empty spaces, or gaps. See WEBSTER's II NEW RIVERSIDE Dictionary 393 (1984). "Lacunae" are distinguished from "vague concepts" in the GATT 1994 in that vague concepts occur when negotiators address an issue and lacunae occur when negotiators do not address an issue. See Jacques H. J. Bourgeois, AntiDumping Law, in INTERNATIONAL TRADE LAW AND THE GATT/WTO DISPUTE SETTLEMENT SYSTEM 302 (Emst-Ulrich Petersmann ed., 1997).

135. Bourgeois, supra note 134, at 303. 
Supplemental remedies to the GATT 1994 provided by national legislation (such as the 1916 Act) qualify as lacunae. ${ }^{136}$ One suggested solution to this conflict has been to allow legislation providing supplemental remedies as long as the fundamental principles of the GATT 1994 are not violated. ${ }^{137}$

But there is a question of whether the negotiators of the General Agreement ever intended that the fundamental principles be anything more than a guide, rather than a chain, to the enactment of national trade legislation. The United States, ever mindful of its national sovereignty, provided in its implementing legislation the following: "No provision of any of the Uruguay Round Agreements, nor the application of any such provision to any person or circumstance, that is inconsistent with any law of the United States shall have effect."138

Moreover, as the Uruguay Round progressed, amendments to the antidumping provisions of the General Agreement became of principal importance to most of the nations that ratified the Final Act. ${ }^{139}$ Given the amount of attention that the Antidumping Agreement received during the round of negotiations, coupled with the increased use of the General Agreement's antidumping provisions internationally in recent years, it seems unlikely that the possibility of nations enacting laws like the 1916 Act was mistakenly overlooked by its negotiators. In other words, such laws are lacunae. Therefore, the GATT 1994 may authorize the passage of such laws

136. See id.

137. See id.; Alford, supra note 2, at 729-32. See also Horlick \& Shea, supra note 8 , at 710-12, on dispute settlement. Developing a solution that provides a proper balance between national sovereignty and international coordination is not an easy task. See Steven P. Croley \& John H. Jackson, WTO Dispute Procedures, Standard of Review, and Deference to National Governments, 90 AM. J. INT'L L. 193, 212 (1996). Stating the issue more precisely:

The problem is how to formulate and articulate the necessary mediating principle or principles between the international policy values for which a dispute settlement is desired, on the one hand, and the remaining important policy values of preserving national 'sovereign' authority both as a check and balance against centralized power, and as a means to facilitate good government decisions close to the constituencies affected, on the other hand.

Id. World Trade Organization panels should be wary not to adopt activist postures in solving disputes among participating members. See id. Activism "could well alienate members, thus threatening the stability of the GATT/WTO dispute settlement procedure itself." Id. See Akakwam, supra note 109, at 277, for further commentary on the appropriate standard of review for panel decisions on antidumping.

138. 19 U.S.C. \$ 3512(a)(1) (1994). See also Terence P. Stewart, The Uruguay Round Agreements Act: An Overview of Major Issues and Potential Trouble Spots, in THE WORLD TRADE ORGanization: THE MULTILATERAL TRADE FRAMEWORK FOR THE 21 ST CENTURY AND U.S. IMPLEMENTING LEGISLATION 29, 38-40 (1996) (quoting Ambassador Kantor's November 23, 1994 letter to Senator Dole). Cf. Horlick \& Shea, supra note 8, at 709 (supporting use of anticircumvention measures).

139. See Dunn, supra note 7, at 239. For a detailed negotiating history of the Uruguay Round Antidumping Agreement, see Horlick \& Shea, supra note 8, at 686-703. 
by implication from its silence. Even if this conclusion is somewhat of a stretch, the 1916 Act itself may be permissible under the General Agreement by being grandfathered in as existing legislation. ${ }^{140}$ If this is so, what should prevent other nations from enacting similar laws to afford their citizens the same protection as citizens of the United States? This question as it applies to supplemental remedies is examined in the next Part.

\section{SUPPLEMENTARY REMEDIES AND THE GATT 1994}

Although the fundamental principles of the General Agreement ${ }^{141}$ are indeed sound and logical, it has been agreed by the Final Act signatories that instances of injurious dumping should form an exception to these principles. ${ }^{142}$ To the extent that remedies are deemed appropriate, ${ }^{143}$ the question remains whether current antidumping remedies are the best solution to the problem. In answering this question, nations should have the flexibility under the GATT 1994 to pass legislation entitling their citizens to supplementary remedies, particularly to a private antidumping remedy, to resolve shortcomings of the GATT 1994 remedies, benefit domestic economies, and ultimately strengthen national security.

\section{A. The Need to Resolve Shortcomings in the GATT 1994}

National legislation should be applied as needed to resolve shortcomings of the GATT 1994 remedies consisting of failure to adequately deter dumping and lack of compensation for the injured industry. The failure of the GATT 1994 remedies in providing adequate deterrence to dumping begins with the slow administrative procedures that implement them. ${ }^{144}$ The speed at which antidumping duties are implemented is critical because the remedy is generally prospective. ${ }^{145}$ Provisional measures may only be applied after sixty

140. See Alford, supra note 2 , at $720-21$.

141. See supra text accompanying notes 102-05.

142. See supra text accompanying notes 115-18.

143. See supra text accompanying notes 106-08.

144. See Note, supra note 89, at 1555; Moller, supra note 17, at 954. An investigation of the alleged dumping may only begin when there is sufficient evidence and sufficient support for a private application by or on behalf of the domestic industry. See Antidumping Agreement art. 5, paras. 2-4. See also supra text accompanying notes 121-24. The latter requirement entails that an applicant must canvass domestic producers prior to submitting an application. See Raworth, supra note 32, at B-39. The investigation itself may take as long as 18 months. See Antidumping Agreement art. 5, para. 10. Further slowness may occur through incompetence in administrative enforcement of antidumping measures. See Moller, supra note 17, at 954 (citing an example in the semiconductor industry).

145. See Note, supra note 89, at 1555; Alford, supra note 2, at 714-15; Moller, supra note 17 , at 954 . 
days from the start of the investigation. ${ }^{146}$ "[F]inal anti-dumping duties may be levied retroactively for the period for which provisional measures applied" upon a final determination that there was material injury, or that there would have been material injury without the protection of the provisional measures, to the domestic industry. ${ }^{147}$ "Retroactive anti-dumping duties may even be levied on products that entered the country up to [ninety] days prior to the date of application of the provisional duties, although they may not affect products that entered prior to the date when the investigation was initiated." 48 However, in cases of material retardation or when there is a material threat of injury alone, retroactive duties are not permitted. ${ }^{149}$ The limits to the retroactive duties and procedural delays can amount to a great deal of harm to domestic industry. A sudden dumping of foreign goods into a domestic market may cause "irreparable damage on domestic industries" as a result. ${ }^{150}$ Lacking a suitable retroactive remedy also amounts to a "risk[-]free, no-lose proposition" for the dumping foreign producer. ${ }^{51}$ The slow procedures are aggravated by the ability of foreign companies to circumvent the Antidumping Agreement. ${ }^{152}$ For example, foreign producers have circumvented antidumping measures by assembling products "in third countries in whole or in part from components and parts produced in the exporting country."153

The second shortcoming of the GATT 1994 is its failure to compensate domestic industry injured by dumping. For instance, under the current system, antidumping duties imposed on foreign producers in the United States are retained by the U.S. government. ${ }^{154}$ The injured domestic manufacturer or importer may gain a victory as a result of making a private application as outlined in the GATT 1994, ${ }^{155}$ but the victory is a hollow one. A ruined business is all that may remain for the domestic producer. ${ }^{156}$ Even if the business survives, the domestic producer is still deprived of capital needed to re-attain its former market position. ${ }^{157}$ This is an injustice to domestic

146. See Antidumping Agreement art. 7, para. 3. See also supra text accompanying note 128.

147. Raworth, supra note 32, at B-40. See also Antidumping Agreement art. 10, para. 2.

148. Raworth, supra note 32, at B-40.

149. See id.; Antidumping Agreement art. 10, para. 2.

150. Moller, supra note 17 , at 954 .

151. Alford, supra note 2, at 713.

152. See id. at 713-14; Note, supra note 89, at 1555.

153. Horlick \& Shea, supra note 8, at 696. The European Community has faced this tactic and imposed "an antidumping duty on copiers from Japan to machines assembled in California." Id.

154. See Alford, supra note 2, at 715; Moller, supra note 17, at 954; Note, supra note 89, at 1555 .

155. See supra text accompanying notes 120-25.

156. See Alford, supra note 2, at 715.

157. See Note, supra note 89 , at 1555. 
producers. $^{158}$

Despite the two shortcomings of the GATT 1994 advanced above, national legislation as a cure may be deemed discriminatory to foreign producers. ${ }^{159}$ First, a foreign producer may be faced with having to defend itself in two forums. ${ }^{160}$ With the 1916 Act in the United States, the two forums are the International Trade Commission and the federal courts. ${ }^{161}$ Second, a foreign producer may not have the same national legislation in its home country, making the balance unequal. ${ }^{162}$ Although there is an element of discrimination shown in these two points, it must be remembered that dumping is the reason for the discrimination, not ordinary trade in goods. Dumping brings with it market inefficiency, and as such, dumping should not be afforded the same respect as legitimate trade. ${ }^{163}$ It was for this reason (unfair price competition producing market inefficiency) that there is an Antidumping Agreement in the GATT 1994. ${ }^{164}$ Hence, shortcomings of the GATT 1994 remedies, failure to deter dumping adequately and lack of compensation for the injured domestic producers, should permit resolution by national legislation.

\section{B. Benefits to Domestic Economies}

Supplemental remedies to those provided in the GATT 1994 can also benefit domestic economies. A foreign producer engages in unfair price competition when it dumps goods, creating market inefficiency. ${ }^{165}$ Although the dumping may be efficient from the producer's perspective because it takes advantage of the experience curve and economies of scale, ${ }^{166}$ the end result is market inefficiency when competitors are driven out of the market and a monopoly is created. ${ }^{167}$ Once the producer gains a monopoly, the inevitable result is that fewer goods will be manufactured at a higher price to consumers to maximize the producer's profit. ${ }^{168}$ Potential competitors will also be discouraged from entering the monopolized market if predatory dumping may

158. See Alford, supra note 2 , at 715 .

159. See id. at 741 . Recall that nondiscriminatory trade is a fundamental principle of the GATT 1994. See id. at 702; WTO Agreement preamble, para. 4.

160. See Alford, supra note 2, at 702.

161. See Geneva Steel Co. v. Ranger Steel Supply Corp., 980 F. Supp. 1209, 1211 (D. Utah 1997); Alford, supra note 2, at 709-10; Note, supra note 89, at 1555-56.

162. See Alford, supra note 2 , at 741.

163. See supra text accompanying notes 24-28.

164. See Hurabiell, supra note 41 , at 572.

165. See supra text accompanying notes 24-25.

166. See supra text accompanying notes $16-20$.

167. See supra text accompanying notes 24-26.

168. See Moller, supra note 17 , at 933 . A monopoly is not necessary to achieve a similar result. See id. The producer only needs to gain a high enough market share to become a pricesetter in the industry. See id. 
be resumed at any time by the foreign producer to protect its interests. ${ }^{169}$

Besides the ruination of the existing (and any future) domestic industry and the harm done to consumers, there are clearly extended effects. There are losses to investors in those ruined domestic industries. ${ }^{70}$ Industry employees also lose their jobs. ${ }^{171}$ All of the preceding cut tax revenue. ${ }^{172}$ In sum, dumping on a wide scale can cause a decline in domestic productivity, economic depression, and a lower standard of living. ${ }^{173}$ To prevent these ill economic effects, it is wise to take additional national legislative measures when the GATT 1994 fails to provide the required antidumping protection.

Some critics have reached the conclusion that any antidumping remedy is bad for an economy despite a growing support for these measures. ${ }^{174}$ They argue that "antidumping laws do more harm than good"175 because they are concerned with protectionism rather than economic predation. ${ }^{176}$ They claim that the "implicit economics" is poor because the gains will exceed the losses to domestic interests from dumping. ${ }^{177}$ Domestic consumers, who some claim are the "larger half of the relevant economics" (domestic producers compose the smaller half), are benefitted by lower prices more than they and the domestic producers are harmed by the economic losses caused by the dumping. ${ }^{178}$ Jobs lost in one industry can be offset by gains in another industry. ${ }^{179}$ On the other hand, a domestic producer protected by antidumping laws may result in lessened competition, which will allow it to keep prices higher on its products or allow it to lower product quality. ${ }^{180}$ Thus, it is argued that by aiding the injured domestic producer, there is a form of wealth distribution. ${ }^{181}$ In essence, critics claim that the market is self-regulating, ${ }^{182}$ and that "the availability of an alternative supplier is the best defense against a predatory seller." 183 Thus, as long as markets remain open to international

169. See id. at 964.

170. See id. at 951.

171. See id. at 951, 964; Hurabiell, supra note 41, at 600-01.

172. See Moller, supra note 17, at 964.

173. See id. at 951.

174. See supra text accompanying notes 109-13.

175. Hurabiell, supra note 41, at 601 . See also Finger, supra note 107, at 64 .

176. See Finger, supra note 107, at 64; Patrick Chisholm, Abolish the Anti-Dumping Law, J. OF COM., Oct. 30, 1998, at 4A, available in LEXIS, News Library, Joc File.

177. Finger, supra note 107 , at 64.

178. Id. at $64-65$ \& $n .4$.

179. See id. at 64. An example is the U.S. cut flower industry. See id. Jobs and profits were lost by domestic growers from dumping, but employment and profit gains were made by flower distributors in the United States. See id.

180. See Hurabiell, supra note 41, at 601 . See also Moller, supra note 17, at 935.

181. See Hurabiell, supra note 41 , at 601 .

182. See id.

183. Finger, supra note 107 , at 64 n.4. 
competition, predatory competition will be contained. ${ }^{184}$ However, the world economy is more complex than any economic theory can account for. It is difficult to accurately tabulate the net benefit or loss to a society from antidumping regulations. ${ }^{185}$ Often it is easier to overstate the benefit of lower prices to consumers because it is more widely dispersed. But those gains can be short-lived if the dumping drives competition out of the subject market. ${ }^{186}$ Thus, the fortunes of both domestic consumers and domestic producers may be more closely tied than what has been previously credited. ${ }^{187}$ Furthermore, alternative suppliers may not always be available in an open market in an imperfect world to keep prices low. In any case, one can expect price volatility in a market that openly allows dumping, as there would be waves of unfair price competition followed by monopoly profits. ${ }^{188}$

Critics also claim that there are nonpredatory economic reasons for dumping that should prevent the use of antidumping measures. ${ }^{189}$ First, a producer "may set different domestic and export prices in response to varying demand conditions." 190 Second, a producer may dump its products in order to sell them before obsolescence. ${ }^{191}$ Third, dumping may occur as a result of lowering a product's price in order to match the price of the competition. ${ }^{192}$ These amount to procompetitive reasons for dumping.

However, since the types of dumping described generally cause no injury that would particularly concern national legislators, the solution is careful drafting of supplementary antidumping laws so as not to necessarily encompass them in their remedies. The solution to varying demand conditions is to determine dumping based on cost of production plus other reasonable costs and a reasonable profit. ${ }^{193}$ Dumping in order to avoid obsolescence is inefficient, ${ }^{194}$ but it is likely that domestic producers are also drastically lowering prices to avoid greater losses with obsolescence. Thus, the product cannot be said to be less than its normal value, and so, may not really be

184. See id.

185. It is suggested that an antidumping investigation should focus on "national economic interest" that takes into account the net benefit to a nation of applying an antidumping measure. Id. at 70. But such an analysis seems inherently unworkable by the complexity of any such computation.

186. See supra text accompanying notes $65-73$.

187. See Moller, supra note 17, at 935 . "[M]ost people in society wear one hat as producers in the work place and another hat as consumers. Hence, when domestic producers are economically damaged, consumers also suffer ...." Id.

188. See supra text accompanying notes 65-69.

189. See Alford, supra note 2, at 705.

190. Id.

191. See id.

192. See id. at 705-06.

193. See supra text accompanying note 10.

194. See supra text accompanying notes $27-28$. 
dumping. ${ }^{195}$ Dumping to match the competition can be addressed as dumping to meet varying demand conditions. Hence, supplementary remedies to the GATT 1994 can benefit domestic economies.

\section{Strengthening National Security}

Nations should have the most flexibility to implement supplementary remedies to those provided in the GATT 1994 when a nation's security is at stake. This is because the existing framework of the GATT 1994 assumes that the primary concern of producers internationally is consumers and corporate profitability. ${ }^{196}$ Although this may be true for countries like the United States, other member countries follow a form of capitalism that is more closely tied to national policy and achieving national objectives. ${ }^{197}$ Americans may fail to recognize that business activity is closely related to national interests in other countries such as Japan. ${ }^{198}$ In such countries, business and government work as one to achieve national goals. ${ }^{199}$ National goals can include any number of aspirations: maintaining national employment, economic expansion, international prestige in an industry, or military might. ${ }^{200}$

One successful method for attaining these goals is dumping. ${ }^{201}$ To consumers, the low prices that attend dumping are viewed as a gift, but predatory dumping can extract a high price from them in the long term. ${ }^{202}$ To support the march to dominance in a particular industry via dumping, the

195. See supra text accompanying notes 9-11.

196. See Moller, supra note 17 , at 958.

197. See id. "Despite the preoccupation with market share that exists within segments of the international market, antitrust enforcers continue to assume that all market participants value profit-maximization over growth." Wesley A. Cann, Jr., Internationalizing Our Views Toward Recoupment and Market Power: Attacking the Antidumping/Antitrust Dichotomy Through WTO-Consistent Global Welfare Theory, 17 U. PA. J. INT'L ECON. L. 69, 169 (1996).

198. See Moller, supra note 17, at 958-62. For an extended discussion over the ties between business and government in Japan, see Fisher, supra note 13, at 114-17.

199. See Wheeling-Pittsburgh Steel Corp. v. Mitsui \& Co., 35 F. Supp. 2d 597, 604 (S.D. Ohio 1999) (International trade "is frequently conducted by companies owned, controlled, or subsidized by foreign governments."); Moller, supra note 17, at 962 .

200. See Stewart, supra note 138, at 51; Moller, supra note 17, at 958; Note, supra note 89, at 1565. A federal court listed the following possible national goals:

A foreign government may decide that it is more beneficial for one or more industries to increase both international and U.S. market shares and to continue to manufacture products, provide employment to its citizens, recoup government investment in what might be an otherwise idle plant, receive hard currency from the sale of exports, or simpiy protect powerful local economic interests, even though products are sold at a loss.

Wheeling-Pittsburgh Steel, 35 F. Supp. 2d at 604.

201. See Moller, supra note 17, at 959.

202. See id. See also supra text accompanying notes 165-73. 
foreign producer will be subsidized by its government. ${ }^{203}$ Allowing a foreign producer to reap monopoly profits in its home market by not having or ignoring antitrust laws is a popular method that governments use to subsidize strategic industries. ${ }^{204}$ As the dumping producer strengthens its market share on the domestic market and gains full advantage of the experience curve and economies of scale, the producer will also gain a technological advantage against its competitors . ${ }^{205}$ Domestic producers will be less able to spend on research and development (R\&D), as they are squeezed out of the market by the dumping. ${ }^{206}$ At the same time, the foreign producer will be able to invest more and more in R\&D as its costs decrease and its subsidies remain in place. $^{207}$ In high growth technological industries, R\&D is critical to the producer's future competitiveness and ultimately to its survival. ${ }^{208}$ Without $\mathrm{R} \& \mathrm{D}$, a producer may earn profits one year, but be out of business the next year. ${ }^{209}$

Beyond the economic harm, loss of technological industries can be especially harmful in matters concerning national security. ${ }^{210}$ Governments that subsidize dumping often focus on technological industries as a source of prestige or power. The industry can be as mundane as electric golf cart manufacturing. ${ }^{211}$ Allegations of dumping by Americans against the Japanese are quite well known. The Japanese have been accused of dumping computer chips from the late seventies to the mid-eighties in order to dominate the semiconductor industry. ${ }^{212}$ They have also been accused of dumping consumer electronic products (CEP) into the United States. ${ }^{213}$ In Zenith Radio, ${ }^{214}$ it was alleged that Japanese CEP makers conspired to keep prices artificially high in Japan to enable them to dump their products in the United States. Although it may be doubtful that such dumping poses an immediate threat to national security, the power of technological development is

203. See Stewart, supra note 138 , at 51 ; Moller, supra note 17 , at 933 ; Note, supra note 89 , at 1566.

204. See Moller, supra note 17, at 933 ; Note, supra note 89, at 1566.

205. See Moller, supra note 17 , at 940.

206. See id.

207. See id.

208. See id. at 948.

209. See id.

210. See id. at 960-61.

211. In Outboard Marine Corp. v. Pezetel, 461 F. Supp. 384 (D. Del. 1978), it was alleged that Polish manufacturers (then operating in a controlled economy) were dumping electric golf carts into the United States.

212. See Moller, supra note 17, at $945-50$. The U.S. Commerce Department and the U.S. International Trade Commission found that the Japanese were in fact dumping computer chips; however, the problem was resolved when a political solution was reached. See id. at 950 .

213. See Zenith Radio Corp. v. Matsushita Elec. Indus. Co., Ltd., 723 F.2d 319, 328 (3d Cir. 1983), rev'd in part, 475 U.S. 574 (1986).

214. See id. 
undeniable. What may be a complex toy today could be the weapon of tomorrow. Thus, it is important for nations to protect against predation of their technological industries.

Nations also need to protect industries that more closely aid in war. For example, agricultural products are essential because "[a]n army marches on its stomach."215 "Japan has been very strong on this point in maintaining its domestic market for rice closed to foreign producers."216 Such a market closure makes particular sense in Japan since, unlike the United States, the "bread basket" of the world, Japan has limited agricultural land in relation to its population. Excessive reliance on other nations for their dietary staples would be devastating in a time of war when international supply lines are slowed or halted. Energy resource development may also be sensitive for national security reasons. In modern mechanized warfare, fuel is essential for mobility of the armed forces. Navy warships, air force jets, and army tanks and jeeps all need fuel merely to come to the battlefield. Additionally, in a war economy, great amounts of energy are required by domestic industry to produce weapons of war. Thus, it makes sense for nations to encourage and protect domestic development of energy resources. Such protection was demanded in Superior Coal Co. v. Ruhrkohle, A.G., ${ }^{217}$ where it was alleged under the 1916 Act that coal and coke products were dumped in the United States by producers from West Germany while fixing a higher price in their homeland. Finally, the steel and steel mill products industry has been highly prized by nations for the employment base it provides and its value for building military strength. ${ }^{218}$ As a result, steel is often overproduced, which leads to dumping. ${ }^{219}$ An example of steel dumping can be found in Geneva Steel, ${ }^{220}$ where it was asserted that Ukraine and Russia had kept producing steel for "political and social reasons."221 In those countries, while they

215. John Bartlett, Familiar QuOTATIONS 505 (Emily Morison Beck ed., 14th ed., Little, Brown and Co. 1968) (1855) (The quotation is attributed to Napoleon I (Napoleon Bonaparte)). See MARCEAU, supra note 12, at 47-48.

216. MARCEAU, supra note 12, at 48.

217. 83 F.R.D. 414,417 (E.D. Penn. 1979).

218. See Stewart, supra note 138 , at 51 .

219. Id.

220. 980 F. Supp. 1209 (D. Utah 1997).

221. Id. at 1211 . Another recent case alleging that Russia dumped steel into the United States in violation of the 1916 Act is Wheeling-Pittsburgh Steel Corp. v. Mitsui \& Co., 35 F. Supp. 2d 597 (S.D. Ohio 1999). Recently, following the "'unprecedented surges in low-priced steel imports from Russia last year," the United States and the Russian Federation reached agreements to reduce imports of steel mill products from Russia and to suspend the current U.S. antidumping investigation of Russian steel mill products. DEP'T OF COM., COMMERCE SECRETARY WILLIAM M. DALEY ANNOUNCES AGREEMENTS SHARPLY REDUCING IMPORTS OF RUSSIANSTEEL (1999). But the agreements do not preclude the U.S. steel industry from filing dumping cases. See id.

Other nations also have been exposed to dumped steel from Russia. A formal 
formed the Soviet Union, steel was needed in high quantities to build the Soviet Union's own military machine. ${ }^{222}$ When the Cold War ended, steel was still being produced at the same rate to preserve employment and obtain hard currency, not for profitability. ${ }^{223}$ So, agricultural, energy resource, and steel production and development are basic to supporting the military, and hence, need additional protections to benefit the national security.

Passing national legislation to provide supplementary private remedies is particularly useful in aiding national security in areas that may otherwise be overlooked when the GATT 1994 remedies are used alone. A private remedy would take disputes a step away from the political arena when the national government would prefer not to get directly involved. After all, imposing an antidumping duty on a nation that is an ally may be a controversial political move. ${ }^{224}$ Furthermore, world peace is promoted because imbalances between nations in terms of technology, agriculture, energy, and steel that are caused by dumping are reduced in a nonpolitical fashion. Nations gain added assurance that industries that are necessary for effective national security are not withered by predatory trade practices. As a result, there is less opportunity for nations to exploit weaknesses of neighboring nations through military action, and instead, they will seek alternative solutions to international conflicts. Nations may still have weaknesses affecting national security, but those weaknesses should not be created by dumping. Thus, nations should retain flexibility to enact supplemental remedies to those provided in the GATT 1994 to strengthen national security.

\section{CONCLUSION}

Nations should have the flexibility under the GATT 1994 to pass legislation entitling their citizens to supplementary remedies, particularly a private antidumping remedy, to resolve shortcomings of the GATT 1994 remedies, benefit domestic economies, and ultimately strengthen national security. The 1916 Act provides an adequate baseline for the flexibility needed by the member nations of the World Trade Organization. Although some claim that the Act is ineffective, the fact that the statute has never been abrogated indicates that "more was expected of the statute than originally

investigation is being conducted by the Chinese government as a result of a complaint alleging that Russian steelmakers are dumping steel into China as well. See John Helmer, Russian Steel Faces Chinese Embargo, J. OF COM., Apr. 12, 1999, at 3A, available in LEXIS, News Library, Joc File. A Canadian investigation has already determined that steel had been dumped into Canada by Russian steelmakers. See Valerie Lawton, Steel Dumping Penalties Upheld, TORONTO STAR, June 2, 1999, available in LEXIS, News Library, Tstar File.

222. See Geneva Steel, 980 F. Supp. at 1224.

223. See id.

224. See Moller, supra note 17, at 956. 
intended. But more importantly, Congress apparently recognized that the [1916] Act plugged a hole in the other unfair competition legislation."22s Nations need supplementary remedies as the 1916 Act provides to navigate around the slow administrative procedures and to provide compensation to domestic industry injured by dumping to regain competitiveness. The 1916 Act empowers producers to take an active role in stopping injurious dumping before their businesses are crippled. Although the requirement of specific intent is a difficult hurdle to clear, the potential recovery of treble damages is sufficient encouragement for producers to start litigation. Alternative remedies also benefit domestic economies by thwarting inefficient dumping, preserving industry, and protecting consumers from foreign monopolies. Although domestic consumers do not always receive the lowest possible price for goods, there is more stability in the domestic market with strengthened antidumping regulations. Consumers are less subject to dramatic price swings from dumping followed by monopoly profits, job losses, and shifts in employment. On a national level, supplemental remedies help prevent the negative economic impacts of dumping: domestic productivity declines, economic depression, and declines in the domestic standard of living. Last, supplementary remedies can strengthen national security by protecting technological, agricultural, energy, and steel industries from injurious dumping. Effectively combating dumping preserves national research and development and those industries that aid in war. Additional private remedies pave a nonpolitical way to resolving dumping conflicts while preventing imbalances that could encourage international aggression. In sum, the independent action of sovereign nations under the general framework of the GATT 1994 is best for each nation and the world.

Adam C. Hawkins

225. Jewel Foliage Co. v. Uniflora Overseas Fla., Inc., 497 F. Supp. 513, 516 (M.D. Fla. 1980). See also Isra Fruit Ltd. v. Agrexco Agric. Export Co. Ltd., 631 F. Supp. 984, 989 (S.D.N.Y. 1986); Schwimmer v. Sony Corp. of Am., 471 F. Supp. 793 (E.D.N.Y. 1979) ("The act is perhaps used to attack different evils today.").

* J.D. Candidate, 2000, Indiana University School of Law-Indianapolis; B.S., 1992, University of Illinois at Urbana/Champaign, College of Commerce and Business Administration. The author would like to thank the Volume 9 Executive Board and Jonathan Faber for their suggestions in perfecting this work. The author would also like to thank those professionals who, although outside the specialty of international trade law, expressed their interest in the completion of this work. 
